\title{
The effect of food deprivation on the fatty acid and lipid profile of red seabream (Pagrus major) larvae
}

\author{
BY A. TANDLER \\ National Centre for Mariculture, Israel Oceanographic and Limnological Research, PO Box 1212, \\ Eilat 88112, Israel \\ AND T. WATANABE AND S. SATOH \\ Laboratory of Fish Nutrition, Tokyo University of Fisheries, Konan 4, Minato-ku, \\ Tokyo 108, Japan \\ AND K. FUKUSHO \\ National Research Institute of Aquaculture, Nansei-cho, Mie Prefecture, 516-01, Japan
}

(Received 2 December 1988-Accepted 10 April 1989)

\begin{abstract}
Under conditions of food deprivation the lipid fraction of red seabream (Pagrus major) larvae shows patterns of conservation or loss in the profile of fatty acids and lipids. These changes were used for qualitative formulation of the dietary requirements of this species. Red seabream larvae were deprived of food for $5 \mathrm{~d}$ after hatching. Their lipid was extracted, weighed and analysed by gas-liquid chromatography and iatroscan for the presence of twenty-four fatty acids including $\boldsymbol{n}$-3 polyunsaturated fatty acids (PUFA), four polar lipids (PL) and four neutral lipids (NL). The results show an exponential decline in lipids with food deprivation, from a mean of 27.7 down to $11.8 \mathrm{mg} / \mathrm{g}$ wet larvae weight $(\mathrm{LW})$. This loss could mainly be attributed to a decline in NL from 22.4 to $7.7 \mathrm{mg} / \mathrm{g} \mathrm{LW}$, in triacylglycerols, from 21 to $1 \mathrm{mg} / \mathrm{g} \mathrm{LW}$, and a change in cholesterol, from $1.3 \mathrm{to} 4.2 \mathrm{mg} / \mathrm{g} \mathrm{LW}$ after $5 \mathrm{~d}$ of food deprivation. PL declined from $5.3 \mathrm{to} 4 \cdot 1 \mathrm{mg} / \mathrm{g} \mathrm{LW}$ in this period. The chief components of this fraction were phosphatidyl choline, and phosphatidyl ethanolamine. Among the fatty acids, the chief decline was observed in saturates and monoenes. Carbon chain lengths of 14 to 18 made up $18.2 \mathrm{mg} / \mathrm{g} \mathrm{LW}$ in hatched larvae, but only $4.8 \mathrm{mg} / \mathrm{g} \mathrm{LW}$ in larvae which were deprived of food for $5 \mathrm{~d}$ after hatching. $n-3$ PUFA were lost at a slower rate, from 5.4 to $3.5 \mathrm{mg} / \mathrm{g} \mathrm{LW}$ for the same period, suggesting that they were conserved. Finally, early larvae of red seabream showed a reduced rate of loss of $n-6$ relative to $n-9$ fatty acids, suggesting that the latter were used preferentially as an energy source.
\end{abstract}

Fatty acids: Starvation: Red seabream larvae

Red seabream (Pagrus major) is a fish of great importance in mariculture in Japan. Rearing of larvae is successful and is associated with a general larval survival of about $30 \%$ in the first $30 \mathrm{~d}$ after hatching (Koronuma \& Fukusho, 1984). However, rearing of larvae is based on the exclusive use of live food; rotifers (Brachionus plicatilis), copepods (Tigriopus japonicus) and brine shrimp nauplii (Artemia salina) (Fukuhara, 1983; Watanabe et al. 1983). The use of inert food as the only initial food for early larvae of red seabream has not been successful (Kanazawa et al. 1982a). Only 10-d-old red seabream and Japanese flounder (Paralichthys olivaceus) larvae feed successfully on a dry diet (Kanazawa et al. 1988). Kanazawa et al. (1982 b) demonstrated the essentiality of eicosapentaenoic acid $(20: 5 n-3)$ in red seabream by using autoradiography. The autoradiograms showed that the labelled fatty acid was incorporated into the swim bladder, gall bladder, liver and pyloric ceacae. Although $23 \cdot 5-\mathrm{g}$ fish were used it was deduced from this study that this fatty acid is an essential dietary component for early red seabream larvae.

The determination of the nutrient requirements of small marine fish larvae is still very 
difficult because of their lack of regular acceptance of formula diets. However, recent pioneering advances in this field have been accomplished by Kanazawa (1985), and Kanazawa et al. (1988), whereby microdiets have been used for the study of the nutrient requirements of red seabream and ayu (Plecoglossus altivelis) larvae.

The objective of the present study was to determine the changes occurring in fatty acids and lipids of newly hatched red seabream larvae which were deprived of food for up to $5 \mathrm{~d}$ after hatching. We believe that under these conditions, patterns of conservation or loss of fatty acids and polar and neutral lipids could give valuable information on the fatty acid and lipid requirements of red seabream larvae for future incorporation into microdiets.

\section{MATERIALS AND METHODS}

Experiments were performed at the National Research Institute of Aquaculture, Nanseicho, Mie prefecture in May 1985. Red seabream eggs were collected daily from 3- and 4year-old spawners with an approximate average weight of $800 \mathrm{~g}$. Twenty-five males and twenty-five females were stocked in a $30 \mathrm{~m}^{3}$ octagonal tank. The tank was equipped with a special net at its overflow to collect the buoyant eggs. Eggs $(400 \mathrm{~g})$ were collected every morning and transferred into a 30 litre circular polycarbonate tank. After swirling the eggs in clean sea water they were left to stand without aeration for about $30 \mathrm{~min}$. Sinking eggs were considered non-fertilized and were siphoned away while buoyant eggs were collected and incubated in well-aerated, running, filtered, seawater for another $24 \mathrm{~h}$. After this period, those eggs which remained buoyant were considered fertilized and were used in the experiments.

Eggs used in the experiment were concentrated on a $0.5 \mathrm{~mm}$ mesh and weighed after blotting dry. Each experimental tank was stocked with 25-g eggs, for a stocking rate of approximately $50 \times 10^{3}$. The experiments were performed in ten 1000 -litre, flat-bottom, circular, polycarbonate tanks. The tanks were placed under a shade to reduce exposure to direct sunshine, and covered with a transparent nylon sheet to reduce the effect of the diurnal temperature variations, and to seal the tanks from possible rainfall.

Each tank was equipped with one large air stone positioned at its centre. The rate of aeration was fixed to $350 \mathrm{ml} / \mathrm{min}$. Of the water volume, $30 \%$ was exchanged daily to reduce the accumulation of metabolites. Measurements of $\mathrm{pH}$ (Corning Instruments) and oxygen (Kent-EIL-7130) concentrations were taken occasionally at noon time, with respective values of 8.28 (95\% confidence interval, C.I., 0.09) and 10.54 mg/1 (C.I. 1.11). The high $\mathrm{O}_{2}$ concentrations corresponded to the high $\mathrm{pH}$ values reflecting a high photosynthetic activity in these tanks. The temperature in the experimental tanks was not regulated, but was never lower than $18 \cdot 0^{\circ}$ and rose in the course of the experiment to $20 \cdot 5^{\circ}$. Daily temperature fluctuations, however, never exceeded $0.4^{\circ}$.

The experiment was a completely randomized design with at least two repetitions per treatment. Hatched red seabream larvae were exposed to six periods of food deprivation: $0,1,2,3,4$ and $5 \mathrm{~d}$. After these periods of food deprivation (starvation) larvae were sampled by draining whole tanks through a $0.5 \mathrm{~mm}$ mesh net. The larvae were then carefully washed, blotted dry, weighed and stored in nylon bags at $-80^{\circ}$ for subsequent analysis.

The frozen samples were analysed for their lipid content (Folch et al. 1957). Fatty acids were methylated (Morrison \& Smith, 1964), dissolved in hexane and analysed on a Shimadzu (model GC-7A) gas-liquid chromatograph (GLC). GLC operating conditions were essentially the same as those described by Watanabe \& Takeuchi (1976). Twenty-four fatty acids, making over $95 \%$ of the methylated fatty acids were identified. Following integration, fatty acids were classified as $n-3, n-6$ and $n-9$ polyunsaturated fatty acids 
(PUFA), the $n-3$ fatty acids having 20 to 22 carbon atom chains. In addition, lipids were analysed for their contents of polar (PL) and neutral (NL) lipids using an Iatroscan (Iatron TH-10, Iatron Laboratories Inc., Tokyo). When using this instrument each sample was developed at least in triplicate. PL were analysed for phosphatidyl ethanolamine (PE), lysophosphatidyl ethanolamine (LPE), phosphatidyl choline (PC), and sphingomyeline (SPM). NL were analysed for triacylglycerols (TG), free fatty acids (FFA), cholesterol (CHO) and diacylglycerols (DG). A solvent mixture of chloroform-acetone-methyl alcohol-acetic acid-distilled water (30:10:7:2:1 by vol.) was used to develop PL, and 1,2dichloroethane-chloroform-acetic acid $(40: 4: 0 \cdot 05$ by vol.) to develop the NL. Known standards were used for identification of PL and NL from the red seabream larvae.

Results were expressed as $\mathrm{mg} / \mathrm{g}$ wet larvae weight (LW), and were analysed by analysis of variance and regression analysis (Steel \& Torrie, 1960). Student-Newman Keuls (SNK) test was used for multiple range analysis (Sokal \& Rohlf, 1969). Effects were declared significant at the $P<0.05$ level.

\section{RESULTS}

Newly hatched larvae of red seabream lost $55 \%$ of their lipid reserves gradually within $5 \mathrm{~d}$ of food deprivation (Fig. 1). The decline in proportion of lipid could be best described using the following equation:

$$
\mathrm{L}=33 \cdot 3 e^{-0.197 T}\left(R^{2} 0 \cdot 8602, P<0 \cdot 01\right),
$$

where $\mathrm{L}$ is lipid as $\mathrm{mg} / \mathrm{g}$ wet $\mathrm{LW}$, and $T$ is larval age in days since hatching.

A closer observation of lipid composition (Table 1) reveals that the decrease in body lipid with food deprivation was associated with a general increase in the proportion of PL. The ratio PL: NL more than doubled in the $5 \mathrm{~d}$ period of food deprivation (Fig. 1). The gain in this ratio is best described by the following equation:

$$
\mathrm{PL}: \mathrm{NL}=2 \cdot 34 e^{0.210 T}\left(R^{2} 0.7927, P<0.01\right),
$$

where $T$ is larval age in days since hatching.

In the lipid fraction the proportion of PL increased significantly with starvation (Table 1) from 192.3 (SE 8.1) at hatching to a peak of 407 (SE 3.0) $\mathrm{mg} / \mathrm{g}$ body lipid after $4 \mathrm{~d}$ of food deprivation and was followed by a decline $(P<0 \cdot 05)$ in the following day to 344 (SE $2 \cdot 0)$ $\mathrm{mg} / \mathrm{g}$ body lipid. PC and PE were the two major polar lipids which contributed to the changes in this fraction. The significant decline in PL on the last day of starvation could be mainly attributed to the changes in PC in the lipid fraction. PC was $164(\mathrm{SE} 6.1) \mathrm{mg} / \mathrm{g}$ lipid at hatching, gradually rising $(P<0.05)$ to 300 (SE 3.4$) \mathrm{mg} / \mathrm{g}$ by $4 \mathrm{~d}$ and followed by a decline $(P<0.05)$ to 255 (SE 17.0$) \mathrm{mg} / \mathrm{g}$ by the 5 th day of starvation. In contrast, PE rose in the $5 \mathrm{~d}$ period of food deprivation from 16.8 (SE 0.9 ) to 62.6 (SE 9.8) $\mathrm{mg} / \mathrm{g}$ lipid, respectively.

In food-deprived red seabream larvae there was a $20 \%$ decline $(P<0.05$; Table 1$)$ in NL in the total lipid fraction. This decline could be mainly attributed to the fall of TG. TG in the lipid fraction decreased $(P<0.05)$ from 755 (SE 5.8) to $88(\mathrm{SE} \mathrm{12.4)} \mathrm{mg} / \mathrm{g}$ lipid (Table 1). On the other hand, two other NL, CHO and FFA rose significantly $(P<0.05)$ within $5 \mathrm{~d}$ of food deprivation, from means of 47.8 (SE 5.0) and 2.7 (SE 1.6) to 356 (SE 65.8) and 193 (SE 60.6) $\mathrm{mg} / \mathrm{g}$ lipid respectively (Table 1 ).

When expressed relative to wet $L W$, PL demonstrated a bell-shaped mode of accumulation and depletion $(P<0.05$, Table 2$)$. This response had a maximum after $3 \mathrm{~d}$ of starvation, rising from $5.3(\mathrm{SE} 0.23) \mathrm{mg} / \mathrm{g}$ wet $\mathrm{LW}$ at hatching to $7.0(\mathrm{SE} 0.95) \mathrm{mg} / \mathrm{g}$ wet LW after $3 \mathrm{~d}$, followed by a decline to $4 \cdot 1$ (SE $0 \cdot 23) \mathrm{mg} / \mathrm{g}$ wet $\mathrm{LW}$ after $5 \mathrm{~d}$ (Table 2 ). Both $\mathrm{PE}$ and PC showed a similar unimodal response $(P<0.05)$ with initial gains from 0.45 


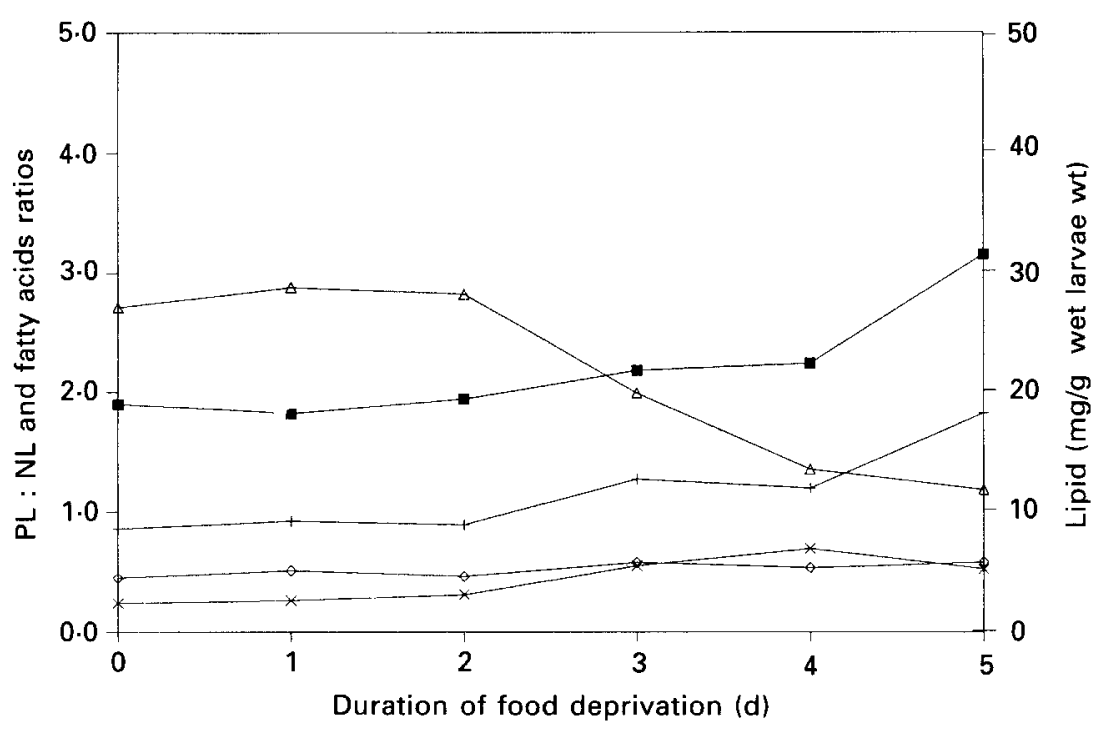

Fig. 1. The effect of the duration of food deprivation on lipid level $(\mathrm{mg} / \mathrm{g}$ wet larvae weight) $(\triangle)$, and on $n-3: n-6(\square), n-3: n-9(+), n-6: n-9(\diamond)$ and neutral lipid (NL):polar lipid (PL) $(\times)$ ratios in red seabream (Pagrus major) larvae. For error terms see Tables 1 and 3.

(SE 0.03) and $4.5(\mathrm{SE} 0.18) \mathrm{mg} / \mathrm{g}$ wet LW at hatching to $1.2(\mathrm{SE} 0.14)$ and $5.4(\mathrm{SE} 0.76) \mathrm{mg} / \mathrm{g}$ wet $\mathrm{LW}$ after $3 \mathrm{~d}$ of food deprivation respectively, followed by respective declines to 0.73 (SE 0.08) and 3.0 (SE 0.4 ) $\mathrm{mg} / \mathrm{g}$ wet LW 2 d later (Table 2).

In the $5 \mathrm{~d}$ period of food deprivation there was a $64 \%$ decline $(P<0.05)$ in NL, from 22.4 (SE 1.2) to $7 \cdot 7$ (SE 0.4) $\mathrm{mg} / \mathrm{g}$ wet LW (Table 2). This decline is best described by the equation:

$$
\mathrm{NL}=27 \cdot 45 e^{-0 \cdot 259 T}\left(R^{2} 0 \cdot 8809, P<0 \cdot 01\right),
$$

where NL is concentration in $\mathrm{mg} / \mathrm{g}$ wet $\mathrm{LW}$, and $T$ is the duration of food deprivation in days since hatching.

The analysis of methylated fatty acids by GLC showed a general increase in the ratios $n-3: n-6$ and $n-3: n-9$ fatty acids (Fig. 1; Table 3 ). The $n-3: n-6$ ratio almost doubled $(P<0 \cdot 05)$ after $5 \mathrm{~d}$ of food deprivation, while the $n-3: n-9$ ratio more than doubled $(P<0.05)$ at this time. It is interesting to note that the $n-6: n-9$ ratio demonstrated a pattern of preferred depletion $(P<0.05)$ of $n-9$ fatty acids on food deprivation. The $n-6: n-9$ ratio rose $30 \%(P<0.05)$ from 0.45 (SE 0.01) at hatching to 0.58 (SE 0.007) after $5 \mathrm{~d}$ of food deprivation.

A closer look at the individual groups of fatty acids shows (Table 3 ) that food deprivation led to a relative increase in $n-3$ compared with $n-6$ and $n-9$ fatty acids. This increase could be mainly attributed to the $n$-3 PUFA with 20 carbon chains or longer. The proportion of $n$-3 PUFA rose about $50 \%(P<0.05)$ in the course of $5 \mathrm{~d}$ of food deprivation, from 199.0 (SE 8.4) to 293.0 (SE 5.7) mg/g body lipid. Moreover, $n-3$ PUFA went from 93.5 at hatch to $98.5 \%$ of the total $n-3$ fatty acids present, after $5 \mathrm{~d}$. The increase in the proportion of $n-3$ PUFA in the lipid fraction in relation to food deprivation is best described by the equation:

$$
n-3 \text { PUFA }=182 \cdot 27 e^{0.0799 T^{\prime}}\left(R^{2} 0 \cdot 8386 ; P<0 \cdot 01\right)
$$

where $n-3$ PUFA is expressed as $\mathrm{mg} / \mathrm{g}$ body lipid, and $T$ is days of food deprivation since hatching.

Correlated with the duration of larval food deprivation, there were drops $(P<0.05)$ in 


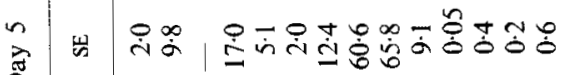

○

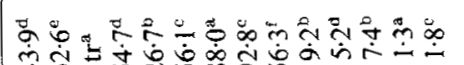

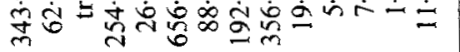

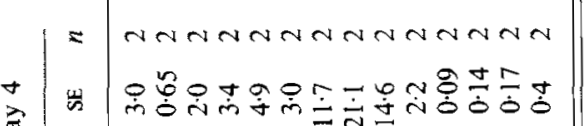

$\triangle$

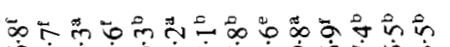

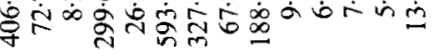

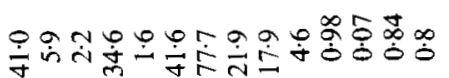

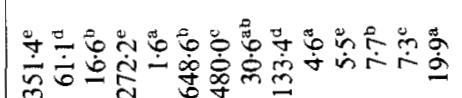
mmmmenmmmmmo N

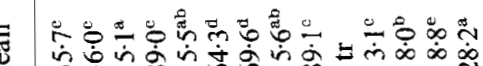

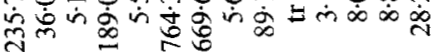
andandannanan$\overrightarrow{2}$

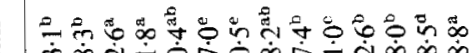

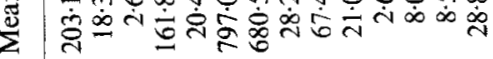

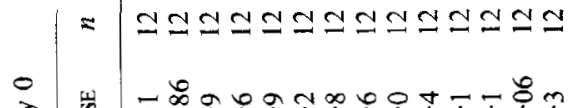
至 崩

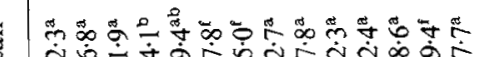

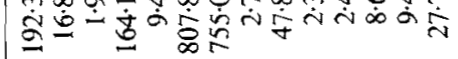

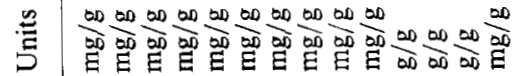
- 
A. TANDLER AND OTHERS
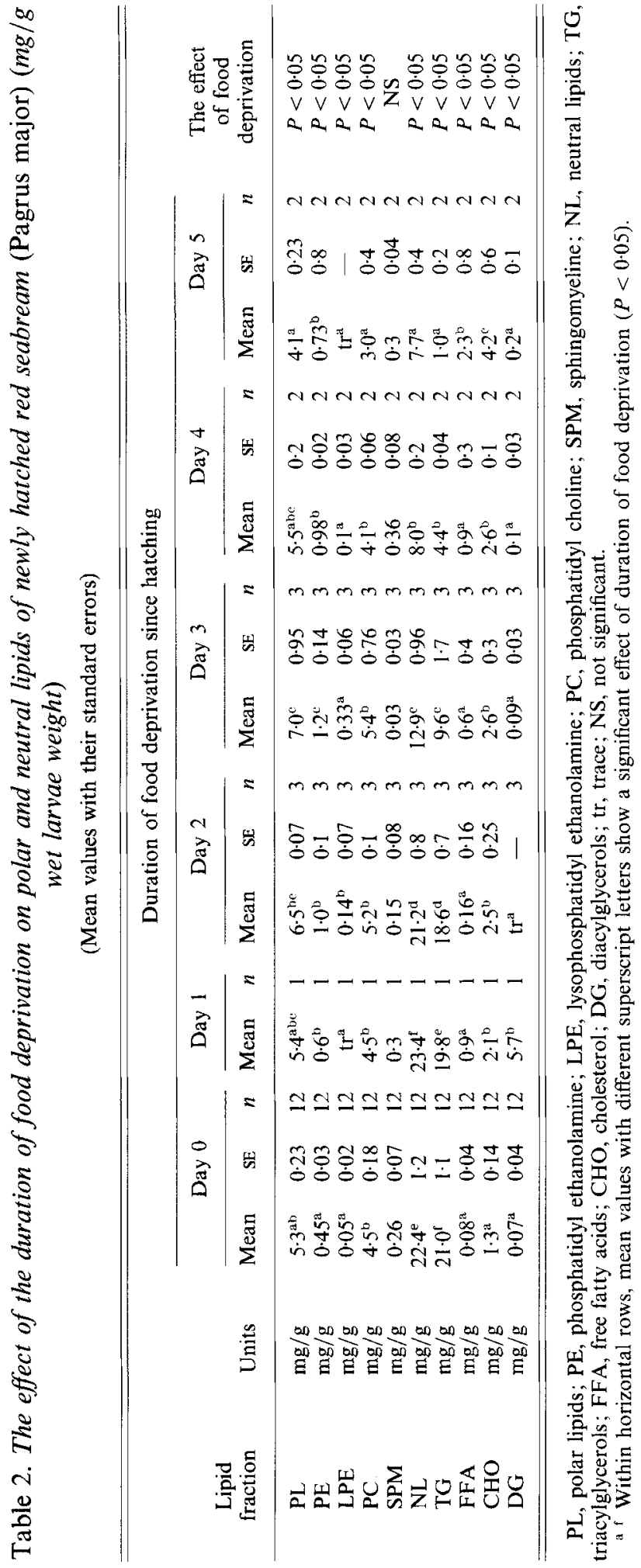


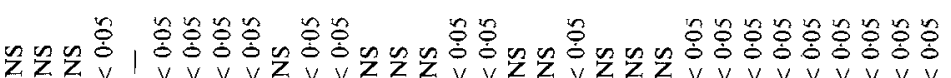

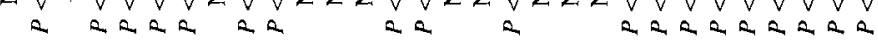

$\stackrel{n}{\stackrel{\mathrm{a}}{\mathrm{a}}}$

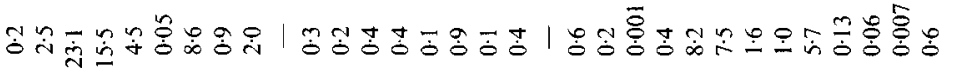

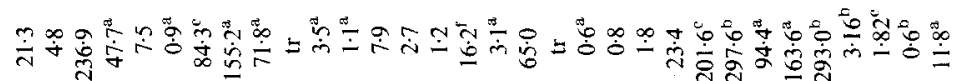

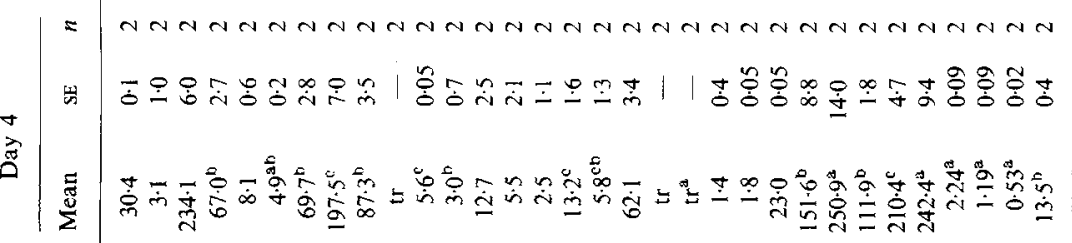

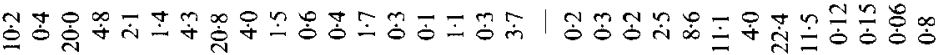

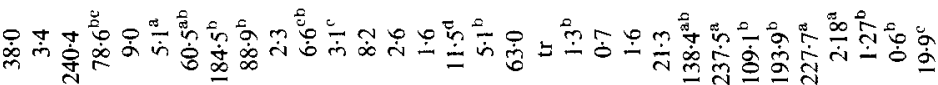

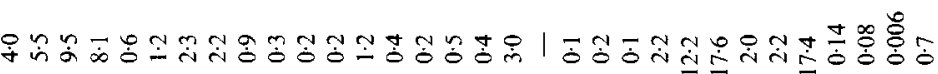

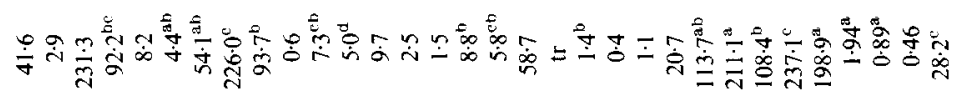

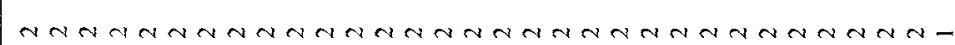

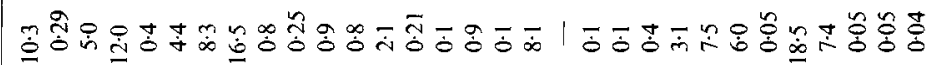

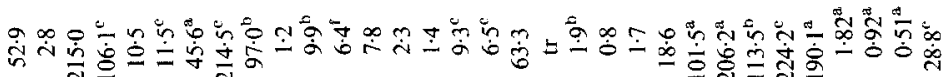
으으으으으으응ㅇㅇㅇㅇㅇㅇㅇ으으으으으응ㅇㅇㅇㅇㅇㅇㅇㅇㅇㅇㅡ

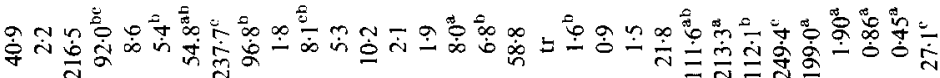

远

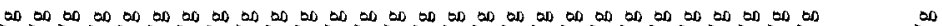
定 * 
the presence of linolenic $(18: 3 n-3)$ and octadecatetraenoic $(18: 4 n-3)$ acids from $8 \cdot 1$ (SE 0.58$)$ and 5.3 (SE 0.58) $\mathrm{mg} / \mathrm{g}$ wet LW at hatch, to 3.5 (SE 0.32) and 1.1 (SE 0.21) $\mathrm{mg} / \mathrm{g}$ wet $\mathrm{LW}$, respectively, for 5-d-old larvae. The only $n$-3 PUFA which showed a decline $(P<0.05)$ was eicosatetraenoic acid $(20: 4 n-3)$, from 6.8 (SE 0.14$)$ to $3-1$ (SE 0.13$) \mathrm{mg} / \mathrm{g}$ wet $\mathrm{LW}$ at hatching and after $5 \mathrm{~d}$ of food deprivation respectively. This decline is indicative of its intermediate position in the $n-3$ chain elongation and desaturation process.

Finally, calculations of the concentration of the different fatty acids as $\mathrm{mg} / \mathrm{g}$ wet $\mathrm{LW}$ showed a negative relationship between the level of all fatty acid groups with the duration of food deprivation (Table 4). Although not significant $(P>0.05)$, there was also a decline in $n-3$ fatty acids. The declines $(P<0.05)$ in $n-6$ and $n-9$ amounted to over $60 \%$ losses within the $5 \mathrm{~d}$ of food deprivation, from $3.0(\mathrm{SE} 0 \cdot 16)$ and $6.8(\mathrm{SE} 0.41) \mathrm{mg} / \mathrm{g}$ wet $\mathrm{LW}$ at hatching, to $1 \cdot 1$ (SE 0.76) and $1.9(\mathrm{SE} 0 \cdot 11) \mathrm{mg} / \mathrm{g}$ wet $\mathrm{LW}$ after $5 \mathrm{~d}$.

\section{DISCUSSION}

Newly hatched larvae of red seabream depleted their lipid reserves when deprived of food, from an initial mean of $27.1 \mathrm{mg} / \mathrm{g}$ wet $\mathrm{LW}$ to $11.8 \mathrm{mg} / \mathrm{g}$ wet $\mathrm{LW} 5 \mathrm{~d}$ after hatching. Under similar conditions Kimata (1983a) found a reduction in total lipid content in red seabream, associated with food deprivation, from 38.2 to $10.7 \mathrm{mg} / \mathrm{g}$. In our study, the relationship between lipid depletion and the duration of food deprivation was exponential; the exponent of the relationship between lipid content and time in days after hatching was $-0 \cdot 197$, with temperatures never falling below $18.0^{\circ}$. This is higher than the exponent of -0.159 which was calculated for Kimata's $(1983 a)$ results on red seabream larvae, which were reared at an average temperature of $19^{\circ}$, but with a minimum temperature of $16^{\circ}$. Tocher et al's (1985a) results on Atlantic herring (Clupea harengus), which were obtained at a lower environmental temperature of $8-10^{\circ}$, gave an exponential loss in total lipids from $40.8 \mathrm{mg} / \mathrm{g}$ wet $\mathrm{LW}$ at hatch ( $22 \mathrm{~d}$ after fertilization) down to $13.7 \mathrm{mg} / \mathrm{g} 10 \mathrm{~d}$ later. The exponent for their results was $-0 \cdot 112$. The substantial differences in the magnitude of these exponents are possibly associated with the environmental temperature, but are perhaps also species specific. The exponential loss in lipid reserves with food deprivation confirms the role of lipid as a major energy reserve in fish (Ehrlich, 1974; Love, 1980). However, Kimata's (1983a) results on red seabream suggest that under conditions of food deprivation, protein is catabolized at a slightly higher rate.

The ratio PL: NL in red seabream in the present study was correlated with the duration of food deprivation. The sparing of PL, under conditions of food deprivation, has already been shown by Takeuchi \& Watanabe (1982). They observed an increase in the PL:NL ratio, from an initial 0.175 to 0.406 , in adult carp (Cyprinus carpio) which were deprived of any food for $86 \mathrm{~d}$. In contrast to our results which show a clear increase in the presence of PL, Kimata's (1983a) results on red seabream showed a marked rate of consumption of $P L$ in fertilized eggs with a resulting reduction of the PL:NL ratio from $0 \cdot 26$ to 0.12 at hatching. This reduction was followed by an increase in the PL: NL ratio to 0.32 after another $5 \mathrm{~d}$. This is lower than the ratios recorded in the present study which exceeded 0.5 . The chief requirements of PL for membrane construction (Kanazawa, 1985) would support the trends of sparing of PL by NL, which were found in our study, while the reduction in PL proportion observed by Kimata $(1983 a)$ is not clear to us. However, it is consistent with the results of Tocher et al. (1985a) on eggs and larvae of Atlantic herring, which suggested a preferred consumption of PL to NL.

$\mathrm{PL}$ concentration $(\mathrm{mg} / \mathrm{g}$ wet $\mathrm{LW}$ ) responded in a bell-shaped fashion to the duration of food deprivation. It is interesting to note that $P L$, in the initial $3 \mathrm{~d}$ period of food deprivation, appeared not only to be spared by a preferred consumption of NL but seemed 


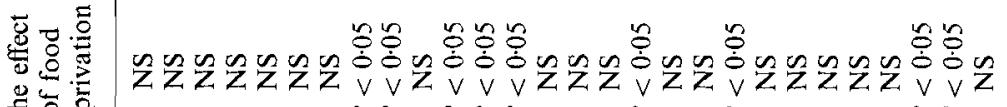

a. 2

a 2

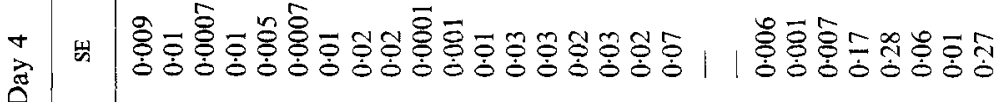

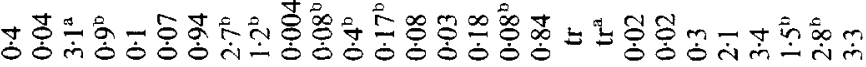

m W

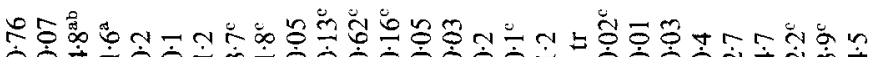
ठठ

N|

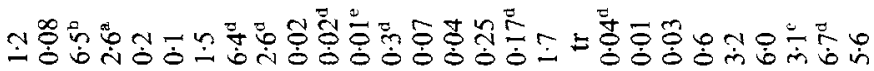

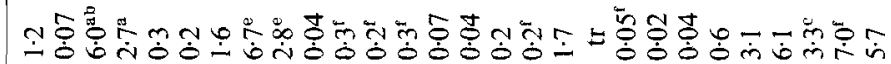
- 으응ㅇㅇㅇ으으으으으으으으응ㅇㅇ으으으으으

市

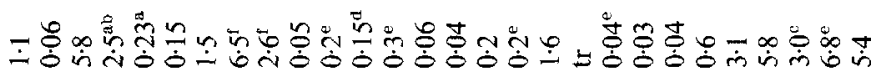

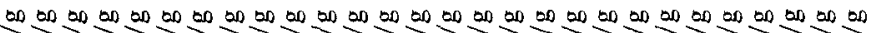

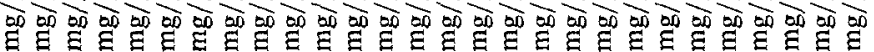


to continue to be synthesized, and increased from 5.3 to $7.0 \mathrm{mg} / \mathrm{g}$ wet $\mathrm{LW}$. The gain in PL in food-deprived red seabream is intriguing. To compensate for energy requirements after a longer period of food deprivation the larvae probably utilize their PL reserves and hence there is a decline on day 5 after hatching to $4.1 \mathrm{mg} / \mathrm{g}$ wet $\mathrm{LW}$. The chief constituent of the PL fraction was PC. In fact, changes in the presence of this phospholipid were responsible for the chief changes in the PL fraction. However, unlike the case with Atlantic herring (Tocher et al. 1985a), where the only increase in the level of PC was in the first $3 \mathrm{~h}$ after fertilization, we observed in red seabream larvae an increase in this phospholipid for $3 \mathrm{~d}$ after hatching; from 4.5 to $5.4 \mathrm{mg} / \mathrm{g}$ wet $\mathrm{LW}$. In contrast, in herring larvae (Tocher et al. 1985 a) PC was lost at a higher rate than the general loss in lipid due to food deprivation, from $13.9 \mathrm{mg} / \mathrm{g}$ wet $\mathrm{LW}$ in newly hatched larvae to $3.5 \mathrm{mg} / \mathrm{g}$ wet $\mathrm{LW} 14 \mathrm{~d}$ later. PE in the present study increased from $0.45 \mathrm{mg} / \mathrm{g}$ wet $\mathrm{LW}$ at hatching to $1.2 \mathrm{mg} / \mathrm{g} 3 \mathrm{~d}$ later. In contrast, Tocher et al.'s (1985a) observations on Atlantic herring, based on our calculations, show a continuous decline with food deprivation, from $3.0 \mathrm{mg} / \mathrm{g}$ wet $\mathrm{LW}$ at hatch down to $1.3 \mathrm{mg} / \mathrm{g} 14 \mathrm{~d}$ later. The patterns of gain of $\mathrm{PC}$ or $\mathrm{PE}$ at the beginning of food deprivation are intriguing. Choline, which is required for $\mathrm{PC}$ synthesis in fish, must be supplied by the diet (Halver, 1972). To the best of our knowledge choline stores in the body of larvae, and especially in their yolks, have not been measured. Poultry yolk was reported as a rich source of choline (Merck, 1976) and, provided some of it is unbound, the yolk could be the source of this vitamin for PC synthesis in the young larvae. On the other hand ethanolamine, which is required for PE synthesis, can be produced from serine (West \& Todd, 1961). In support of an internal precursor for ethanolamine synthesis, Kimata (1982) showed a substantial loss of serine in food-deprived larvae of red seabream.

NL declined from 22.4 to $7.7 \mathrm{mg} / \mathrm{g}$ wet $\mathrm{LW}$ within a period of $5 \mathrm{~d}$ of food deprivation. A similar trend but with substantially higher levels of NL was reported by Kimata (1983a) in red seabream, with a decline in NL from 45.2 to $23.5 \mathrm{mg} / \mathrm{g}$ wet $\mathrm{LW}$. In agreement with these observations, hatched Atlantic herring (Tocher et al. 1985a) showed a decline in NL, from $18.4 \mathrm{mg} / \mathrm{g}$ wet $\mathrm{LW}$ at hatch to $5.4 \mathrm{mg} / \mathrm{g} 10 \mathrm{~d}$ later. In $12.8 \mathrm{~g}$ carp (Takeuchi \& Watanabe, 1982) NL declined from 42.5 to $2.5 \mathrm{mg} / \mathrm{g}$ wet $\mathrm{LW}$ within $86 \mathrm{~d}$ of food deprivation. Similarly, these authors showed in $28.1 \mathrm{~g}$ rainbow trout (Salmo gairdneri) that liver NL declined from 23 to $13 \mathrm{mg} / \mathrm{g}$ wet $\mathrm{LW}$ after a $43 \mathrm{~d}$ period of food deprivation.

The catabolism of NL in red seabream in our study is well exemplified by the significant increase in both FFA and CHO. The increase in FFA is a result of the hydrolysis of TG, which declined sharply with food deprivation. An increase in FFA was also observed by Tocher et al. (1985a) in food-deprived herring larvae. However, the increase found in their study was limited to the last $4 \mathrm{~d}$ in a $14 \mathrm{~d}$ period after hatching. The very large increase in the presence of FFA with the duration of food deprivation resembles the response of mammals to food deprivation, but is exceptional in fish (Bilinski, 1974). Contrary to our findings, Fraser et al. (1988) found a very slight change in this fraction in food-deprived cod larvae (Gadus morhua). The differing responses of the FFA fraction to food deprivation is typical of fish and is species specific (Love, 1970). CHO, in the present study, also increased with food deprivation. This increase was especially dramatic after $4 \mathrm{~d}$ of deprivation when a sharp decline in PL could be seen. Similarly, Tocher et al. (1985a) observed an increase in $\mathrm{CHO}$ in herring larvae with food deprivation. $\mathrm{CHO}$ appears in a free form in intimate association with PL in cell membranes (Christie, 1982). Therefore it is no surprise that it rises when components of cell membranes are being lost.

The fatty acid analysis of red seabream larvae showed a general increase in $n-3$ fatty acids in association with the duration of food deprivation. Concurrently, there was a sharp decline in both $n-6$ and $n-9$ fatty acids. This suggests that $n-6$ and $n-9$ fatty acids serve as 
preferred substrates for catabolism during food deprivation, while $n$-3 fatty acids are conserved. Moreover, our results clearly show that of the two substrates for catabolism, $n$ 6 and $n-9$ fatty acids, the latter group is preferred. A similar pattern of preference of $n-9$ fatty acids, under conditions of food deprivation, was observed by Dave et al. (1975) in the european eel (Anguilla anguilla), and by Jezierska et al. (1982) in rainbow trout. The reasoning for the preference of $n-9$ over $n-6$ fatty acids in the latter studies is based on the difference between the positions of the two groups of fatty acids in terms of their bond in the alpha or beta positions of glycerol. It has been suggested that fatty acids located in the beta position are not as readily hydrolized as those in the alpha position. The greater rate of consumption of monoenes of the $n-9$ group in the european eel and rainbow trout was attributed to their alpha position in the TG molecule (Dave et al. 1975; Jezierska et al. 1982). This suggests the possibility that in red seabream the mobilized fatty acids of the $n-9$ family are more readily hydrolized because they occupy the alpha position on the TG molecule.

We could attribute most of the change in $n-3$, from 213.3 at hatching to $297.6 \mathrm{mg} / \mathrm{g}$ lipid after $5 \mathrm{~d}$ of food deprivation, to the losses in both $n-6$ and $n-9$ fatty acids. Consistent with this pattern, Tocher et al. $(1985 b)$ observed a similar gain in $n-3$ fatty acids, in the NL fraction of Atlantic herring. This gain was mainly due to the monoenes, but also due to the $n-6$ fatty acids. On the other hand, in the PL fraction of Atlantic herring (Tocher et al. $1985 \mathrm{~b}$ ) there was an accelerated loss in $n-3$ fatty acids compared with $n-6$ fatty acids. Kimata's $(1983 b)$ observations on the PL fraction of red seabream larvae do not reveal any clear patterns of fatty acid preference. In the latter study there was a noticeable increase in pentaenoic fatty acids in the NL fraction from 85 to $140 \mathrm{mg} / \mathrm{g}$ lipid, which was associated with decreases in both hexaenoic and saturated fatty acids, from 210 and $310 \mathrm{mg} / \mathrm{g}$ lipid to 170 and $280 \mathrm{mg} / \mathrm{g}$ lipid, respectively. Hence it seems as if the preference patterns which we encountered in the lipid fraction of red seabream for $n-3$ fatty acids are probably limited to the NL fraction, while fatty acids in the PL fraction of food-deprived larvae are catabolized indiscriminately.

We observed a loss in $n-3$ fatty acids with a coinciding gain in $n-3$ PUFA. For example, there was a decline in linolenic acid $(18: 3 n-3)$, from 8.1 to $3.5 \mathrm{mg} / \mathrm{g}$ lipid, after $5 \mathrm{~d}$. On the other hand there was a gain in $22: 6 n-3$ from 111.6 to $201.6 \mathrm{mg} / \mathrm{g}$ lipid in newly hatched and $5 \mathrm{~d}$ food-deprived larvae respectively. This large gain within the lipid fraction could mainly be attributed to a loss in $n-9$ fatty acids. Within this group, 16:1, possibly palmitoleic acid, had the steepest decline, from 92 to $47.7 \mathrm{mg} / \mathrm{g}$ lipid in the course of the study. Such patterns of loss in essential fatty acids and monoenes with a concomitant gain in PUFA was not evident either in $n-6$ or in $n-9$ fatty acids. A very similar pattern to that of red seabream in the present study, both in terms of the accumulation of $22: 6 n-3$ and in losses mainly of $16: 0$ but also in 16:1, was shown by Tocher et al. $(1985 b)$ in Atlantic herring larvae. Kimata's $(1983 b)$ results on red seabream show a doubling in the level of $20: 5$ from 64.2 in fertilized eggs to $111 \mathrm{mg} / \mathrm{g}$ lipid in 6-d-old larvae. This marked increase was limited to the NL, and was correlated to a decline in 16:0. The patterns of depletion and conservation of essential fatty acids and PUFA in fish larvae are consistent with the findings in food-deprived adult fish (Love, 1970; Takeuchi \& Watanabe, 1982; Satoh et al. 1984). This suggests that the metabolic pathways of lipid metabolism in fish larvae are consistent with the models for elongation and desaturation which were proposed by Castell (1979) and Bell et al. (1986).

In conclusion, under conditions of food deprivation, $n$-3 PUFA (mainly docosahexaenoic acid (22:6n-3)), PC and PE emerged as essential dietary components of the early larvae of red seabream. In addition, the dietary inclusion of TG and an $n-6: n-9$ ratio higher than $0 \cdot 45$ would be expected to spare the essential fatty acids from being catabolized. 
The first author wishes to thank Tokyo University of Fisheries and the National Research Institute of Aquaculture at Nansei-cho, Mie prefecture, for their very warm hospitality and support of this project. In addition the authors wish to thank the staff and students at both places, who gave their enthusiastic support to this study. Finally, we wish to thank G. Wm. Kissil, and $\mathrm{W}$. Koven for their critical reading of the manuscript.

\section{REFEREN CES}

Bell, M. V., Henderson, R. J. \& Sargent, J. R. (1986). The role of polyunsaturated fatty acids in fish. Comparative Biochemistry and Physiology $83 \mathrm{~b}, 711-719$.

Bilinski, E. (1974). Biochemical aspects of fish swimming. In Biochemical and Biophysical Perspectives in Marine Biology, vol. 1, pp. 239-288 [D. C. Malins and J. R. Sargent, editors]. London: Academic Press.

Castell, J. D. (1979). Review of lipid requirements of finfish. In Finfish Nutrition and Fishfeed Technology, vol. 1, pp. 59-84 [J. E. Halver and K. Tiews, editors]. Berlin: Heenemann Verlagsgesellschaft mbH.

Christie, W. W. (1982). Lipid Analysis. Oxford: Pergamon.

Dave, G., Johansson-Sjobeck, M.-J., Larson, A., Lewander, K. \& Lidman, U. (1975). Metabolic and hematological effects of starvation in the european eel, Anguilla anguilla L. 1. Carbohydrate, lipid, protein and inorganic ion metabolism. Comparative Biochemistry and Physiology 52a, 423-430.

Ehrlich, K. F. (1974). Chemical changes during growth and starvation of herring larvae. In The Early Life History of Fish, pp. 301-323. [J. H. S. Blaxter, editor]. Berlin, Heidelberg, New York: Springer-Verlag.

Folch, J., Lees, M. \& Stanley, G. H. S. (1957). A simple method for the isolation and purification of total lipids from animal tissues. Journal of Biological Chemistry 226, 497-509.

Fraser, A. J., Gamble, J. C. \& Sargent, J. R. (1988). Changes in lipid content, lipid class composition and fatty acid composition of developing eggs and unfed larvae of cod (Gadus morhua). Marine Biology 99 (3), $307-314$.

Fukuhara, O. (1983). Seed production of red seabream, Pagrus major (Sparidae) in Japan. Paper presented to the 12th joint meeting US/Japan aquaculture panel (UJNR), Louisiana, USA.

Halver, J. E. (1972). The vitamines. In Fish Nutrition, pp. 29-103 [J. E. Halver]. New York, London: Academic Press.

Jezierska, B., Hazel, J. R. \& Gerking, S. D. (1982). Lipid mobilization during starvation in the rainbow trout Salmo gairdneri Richardson, with attention to fatty acids. Journal of Fish Biology 21, 681-692.

Kanazawa, A. (1985). Essential fatty acid and lipid requirement of fish. In Nutrition and Feeding in Fish, pp. 281-298 [C. B. Cowey, A. M. Mackie and J. G. Bell, editors]. London: Academic Press.

Kanazawa, A., Teshima, S., Imalanaka, N., Imada, O. \& Inoue, A. (1982 b). Tissue uptake of radioactive eicosapentaenoic acid in the red seabream. Bulletin of the Japanese Society for Scientific Fisheries 48, $1441-1444$.

Kanazawa, A., Teshima, S., Inamori, S., Sumida, S. \& Iwashita, T. (1982 a). Rearing of larva! red seabream and ayu with artificial diets. Memories of the Faculty of Fisheries, Kagoshima University 31, 185-192.

Kanazawa, A., Teshima, S. \& Koshiko, S. (1988). The growth and survival of larval Japanese flounder Paralichthys olivaceus and red seabream Pagrus major fed microparticulate diets. World Aquaculture Society, 19th annual Meeting, January, 1988 (Abstract).

Kimata, M. (1982). Studies on the metabolism of marine fish eggs IV. Changes of amino acid composition of egg and larva during early development in the red seabream, Chrysophrys major (Temminck and Schlegel). Bulletin of the Institute for Oceanic Research \& Development, Tokai University 4, 71-78.

Kimata, M. (1983a). Changes of chemical composition during early larval development in the red seabream, Chrysophrys major (Temminck and Schlegel) egg and larva. Journal of the Faculty of Marine Science \& Technology, Tokai University 16, 213-223.

Kimata, M. (1983 b). Changes of fatty acid composition during early development in the red seabream Chrysophrys major (Temminck and Schlegel) egg and larva. Joumal of the Faculty of Marine Science \& Technology, Tokai University 16, 225-233.

Koronuma, K. \& Fukusho, K. (1984). Rearing of Marine Fish in Japan. IDRC-TS47e. Ottawa: International Development Research Centre.

Love, R. M. [editor] (1970). Depletion. In The Chemical Biology of Fishes. vol. 1, pp. 222-257. London: Academic Press.

Love, R. M. [editor] (1980). Feeding and Starving. In The Chemical Biology of Fishes. vol. 2, pp. 133-229. London: Academic Press.

Merck (1976). The Merck Index: An Encyclopedia of Chemicals and Drugs [M. Windholtz, S. Budavari, L. Y. Stroumtsos and M. N. Fertig, editors]. Rahway, NJ: Merck \& Co.

Morrison, W. R. \& Smith, L. M. (1964). Preparation of fatty acid methyl esters and dimethylacetals from lipids with boron fluoride-methano1. Journal of Lipid Research 5, 600-608.

Satoh, S., Takeuchi, T. \& Watanabe, T. (1984). Effects of starvation and environmental temperature on proximate and fatty acid composition of Tilapia nilotica. Bulletin of the Japanese Society for Scientific Fisheries 50, $79-84$.

Sokal, R. R. \& Rohlf, F. I. (1969). Biometry. San Francisco: W. H. Freeman and Co.

Steel, R. G. D. \& Torrie, J. H. (1960). Principles and Procedures of Statistics. New York: McGraw-Hill Book Co. 
Takeuchi, T. \& Watanabe, T. (1982). The effects of starvation and environmental temperature on proximate and fatty acid composition of carp and rainbow trout. Bulletin of the Japanese Society for Scientific Fisheries $\mathbf{4 8}$, $1307-1316$.

Tocher, D. R., Fraser, A. J., Sargent, G. R. \& Gamble, J. C. (1985a). Lipid class composition during embryonic and early larval development in Atlantic herring (Clupea harengus, L.). Lipids 20, 84-89.

Tocher, D. R., Fraser, A. J., Sargent, G. R. \& Gamble, J. C. (1985b). Fatty acid composition of phospholipids and neutral lipids during embryonic development in Atlantic herring (Clupea harengus, L.). Lipids 20, 69-74.

Watanabe, T., Kitajima, C. \& Fujita, S. (1983). Nutritional values of live organisms used in Japan for mass propagation of fish: a review. Aquaculture 34, 115-143.

Watanabe, T. \& Takeuchi, T. (1976). Evaluation of pollock liver oil as a supplement to diets for rainbow trout. Bulletin of the Japanese Society for Scientific Fisheries 42, 893-906.

West, E. S. \& Todd, W. R. (1961). Textbook of Biochemistry. New York: MacMillan. 